Jeanette C. Fincke

\title{
Three Nuzi Texts from the British Museum and a Middle Assyrian Letter from the Aftermath of the Conquest of the Kingdom of Arraphe
}

\begin{abstract}
At the end of the $19^{\text {th }}$ and the beginning of the $20^{\text {th }}$ century tablets from chance finds at Yorgann Tepe (Nuzi) and Kirkūk (Arrapha) prior to the first excavations at Nuzi in 1925 entered the tablet collections of various museums all over the world. More than 360 of such Nuzi tablets, dating roughly from the mid $15^{\text {th }}$ to the mid $14^{\text {th }}$ century BCE, have been acquired by the British Museum (henceforth BM) in several individual purchases. Three more Nuzi tablets have now been identified at the Museum and are presented here. One is a list of household personnel (BM 86005), mostly female, receiving wool allotments, and includes some previously unattested Hurrian female personal names. Two are fragments of legal documents, one from the lower right (BM 95280) and the other from the reverse (BM 95463) of their respective tablets. They bear seal impressions and the names of the witnesses sealing the contracts. A letter (BM 103203) is also presented here. It shows both typical Nuzi features (the addressee has a Hurrian name) and Middle Assyrian characteristics. Most importantly, it is dated according to Assyrian custom with a limu, but one that could be either an unusual writing (the scribe may have had a Hurrian background) of a known limu from the reign of Aššuruballit I (Kidin-kūbe), or a new līmu dating to the $14^{\text {th }}$ century BCE (Kitte-kūbe or Qīîi-kūbe).
\end{abstract}

Keywords: Nuzi texts, female Hurrian personal names, MA letter, conquest of Arraphe, līmu of Aššur-uballiṭ I

DOI 10.1515/aofo-2014-0004

The more than 360 so-called Nuzi texts, tablets from the Hurrian kingdom of Arraphe dating from the mid $15^{\text {th }}$ to the mid $14^{\text {th }}$ century, in the BM tablet collection come from chance finds at Nuzi (Yorḡān Tepe) and Arrapha (Kirkūk) from before the excavations at Nuzi began in 1925. Other museums and private collections were collecting them as was the BM, so that tablets from individual archives are now spread over nine tablet collections in several countries, and it is possible that more such Nuzi texts are still to be identified in other collections. Some long-distance joins have been made between different collections (e.g. Wilhelm apud Owen 1981: 459-463; Fincke 1996 and 1998), but these attempts depend on how well the tablets have been published. ${ }^{2}$ Most, but not all, BM Nuzi texts are already published. (An overview of the situation in 2005 is given in Fincke 2009: 239-248.)

\footnotetext{
1 In this article, personal names will be transliterated using the simplest value of the cuneiform signs. Hurrian names will be rendered in the translation preferring the voiceless variant of the consonants to the voiced ones (with a few exceptions), thus applying the standards of studies of the Nuzi texts set up by NPN. It should be noted that these standards reflect neither Hurrian pronunciation nor a Hurrian grammatical analysis. Following the conventions of NPN, divine names will not be capitalised when used as a second or third element of personal names. In order to distinguish between the country and the city, Arraphe refers to the country, but Arrapha to the city, since the writing Arrapha for the city is well established in Assyriological studies. Bibliographical abbreviations follow those of Archiv für Orientforschung, with the following exceptions and additions: AAN = Cassin / Glassner (1977); CDA = Black et al. (1999); Fincke, SCCNH 7 = Fincke (1995); Gadd = Gadd (1926); PNAE 4/I = Baker (2002); RGTC 5 = Nashef (1982); RGTC 10 = Fincke (1993). PN stands for 'personal name'.

2 An edition together with a copy (autograph) is essential for such an attempt, and fortunately most of these tablets have been published satisfactorily.
}

Jeanette C. Fincke: School of Oriental and African Studies, University of London, Thornhaugh Street, Russell Square, London, WC1H 0XG, E-Mail: jeanette.fincke@ori.uni-heidelberg.de 
In October 2013, Christopher Walker informed me of four previously unidentified Nuzi texts. ${ }^{3}$ One is a complete tablet with a list of mostly female personal names (BM 86005), two are fragments from the bottom (BM 95280) and reverse (BM 95463) of tablets of legal documents with seal impressions, and the last one is a small letter in a square format (BM 103203). Upon examining BM 103203 I was able to read a date formula, including a limu-name, revealing that the tablet is not a Nuzi text per se, but a Middle Assyrian letter. Since there are indications that the addressee of this letter was located in Arrapha and that the tablet was most probably found there, it will be presented in this article together with the three Nuzi texts in autograph and edition.

\section{BM 86005: A Ration List of Mostly Female Household Personnel}

This completely preserved tablet (Fig. 1) is a list of household personnel who receive wool as a clothing allotment. Most of the 40 personal names are female, which adds to the relatively small corpus of these names known from the Nuzi texts. Several of these personal names are known from various other Nuzi lists of names: ${ }^{4}$ SANTAG 4, 21 (BM 26227; 30 matching names; receiving barley rations), Gadd 82 (BM 86416; 11 matches; NAM. 'LÚ'.LÚ.MEš, 'personnel', receiving barley rations), TCL IX 22 (6 matches; fragmentary), SANTAG 4, 136 (BM 95397; 5 matches; fragmentary), CT 51, 7 (BM 13158; 4 matches; receiving barley rations), 14 (BM 13316 ; 4 matches; receiving barley rations), SANTAG 4, 34 (BM 26273; 4 matches; sent out as harvest workers).

Of these texts, only SANTAG 4, 34 can be dated: a certain fWištanzu sealed the letter order, who is certainly to be identified with ${ }^{\mathrm{f}} \mathrm{Wištanzu}$, the wife of Zike, son of Šurki-tilla (and grandson of Tehip-tilla), thus representing the fourth generation of the Tehip-tilla family and the third to fourth generation of the family of scribes of Apil-sîn (see Friedman 1987: 116-117). The BM Nuzi tablets include many from the archive of Zike (28 of the 162 in SANTAG 4 published texts name him directly; see also Maidman 1986: 257), so it is likely that BM 86005 also belongs to this archive.

The measurements of BM 86005 are $56 \times 91 \times 25$ mm (Fig. 1).

\section{Transliteration and Translation}

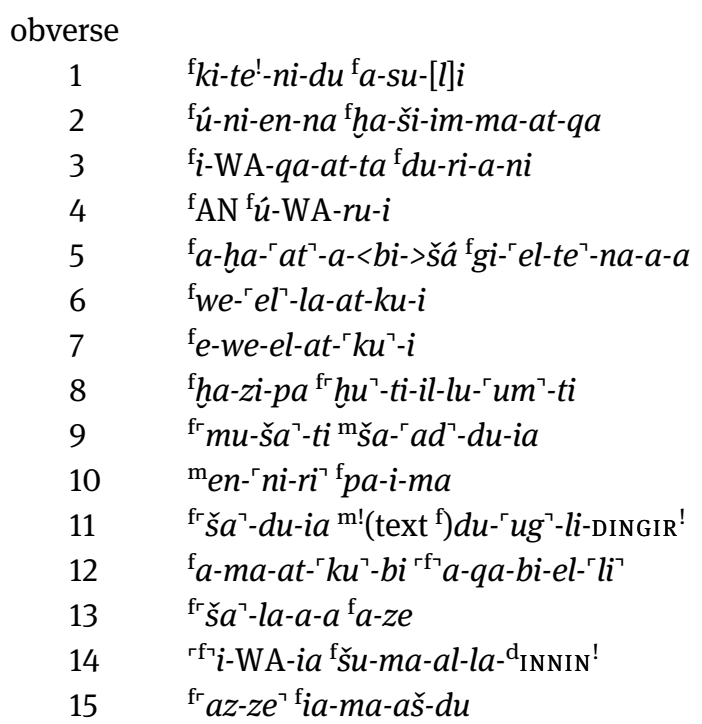

\author{
${ }^{\mathrm{f}}$ Kiden(n)itu, ${ }^{\mathrm{f}}$ Azuli, \\ fUnenna, f Hašim-matka, \\ f Iwa-katta, ${ }^{\text {TTuriani, }}$ \\ fAN, fUwurui, \\ fAhāt-abīša, f Keltennaia \\ fWellat-kui, \\ fEwelat-kui, \\ ${ }^{\text {fHazipa, }}{ }^{\mathrm{f}}$ util-lumti, \\ ${ }^{\mathrm{f}}$ Mušati, m̌̌attuia, \\ mEnniri, fPaima, \\ fŠatuia, m! Dug(u)l-ilī, \\ ${ }^{\mathrm{f}}$ Amāt-kūbi, ${ }^{\mathrm{f}}$ Akap-elli, \\ fŠalaia, ${ }^{\mathrm{f}}$ Aze, \\ fIwaîa, fŠumalla- ${ }^{\mathrm{d}}$ Ištar, \\ fAzzi, İamaštu,
}

3 Originally, Maynard P. Maidman and I, since we happened to be working at the BM at the same time, planned to publish these four tablets as a coauthored article. Because of differing approaches to editing the texts, however, he discontinued his cooperation in January 2014.

4 Only completely preserved names or those that can be restored with certainty are considered. 


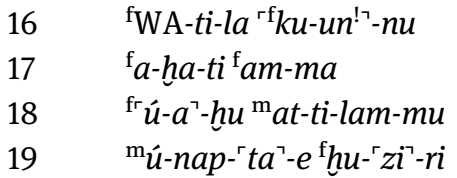

lower edge

20

21

f̌̌ur-'ku'-um-ni-nu

${ }^{\mathrm{rf}}$ ad-dur ${ }^{\mathrm{r}-}-\mathrm{ru}$

reverse

22

23

24

25

26

\author{
${ }^{\mathrm{f}} a n-n u-t e-t i$ \\ ${ }^{\mathrm{f}} k u-t i-a-n i$ \\ $a n-n u-t u_{4} n i-i s ̌$ É 3-TA. ÀM \\ ku-duk-ti sík.Me lu-bu-ul-ta \\ ša il-qú-ú
}

fWatila, ${ }^{\text {fKunnu, }}$

${ }^{\mathrm{f}}$ Ahātī, ${ }^{\mathrm{f}}$ Amma,

fU्रahu, ${ }^{\mathrm{m}}$ Attilammu,

${ }^{\mathrm{m}}$ Unap-tae, ${ }^{\mathrm{f}} \mathrm{Huziri}$,

fŠurkum-ninu,

${ }^{\mathrm{f}}$ Atturru,
${ }^{\mathrm{f}}$ Annu-teti (and)
fKutiani;
these are the household personnel; each
(person) has received (an allowance of) 3
kuduktu-measures of wool (as) clothing.

\section{BM 86005}

Obverse

10

15

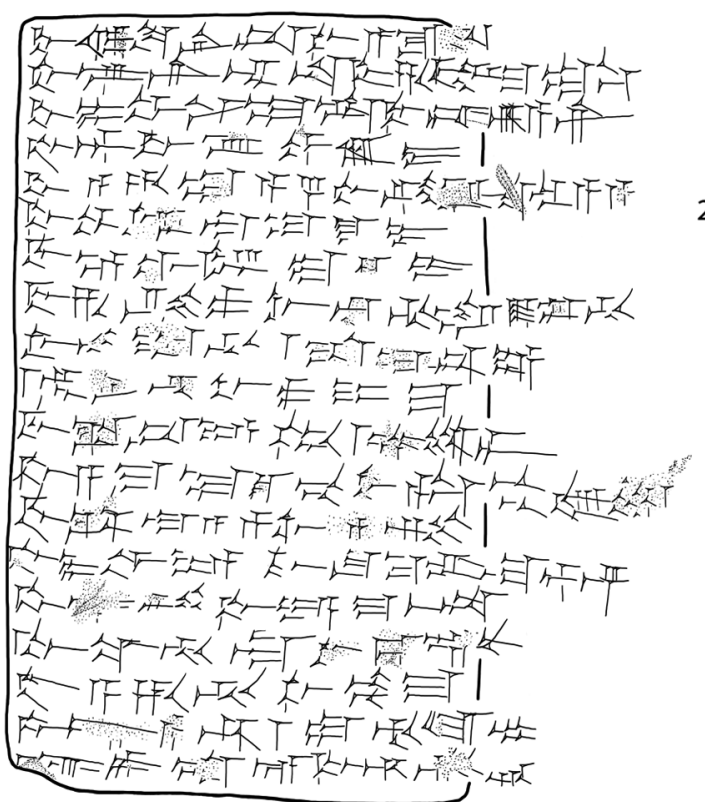

20

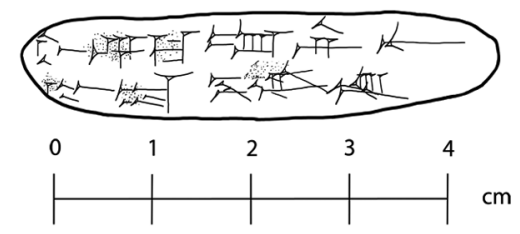

Reverse

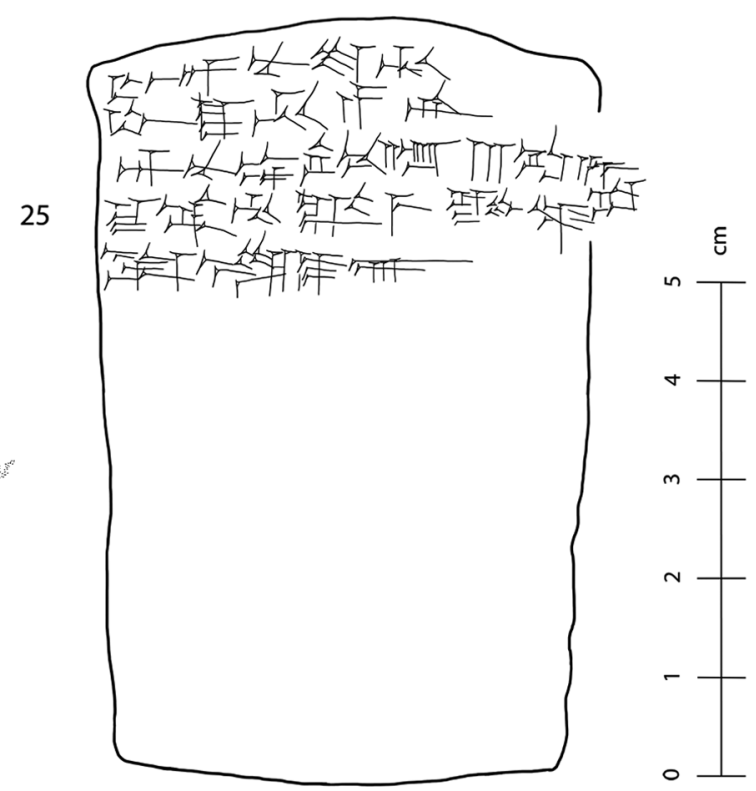

Fig. 1: BM 86005.

\section{Notes}

obv. 1 The second cuneiform sign of fKiden(n)itu should be read - $t e^{!}$in light of SANTAG 4, 21 obv. 6, JEN 507 obv. 12 and JEN 516 obv. 10 (quoted NPN 98a as KITENÎTU). The sign on the tablet, however, looks as if the scribe could not decide whether to write DI or TE. The name itself is most probably 
kidinnitu, 'protégée', feminine of kidinnû, 'protégé': the PN is well attested in Babylonian texts from the Middle Babylonian period onwards (see CAD K 344a and AHw 473a, with examples for writings with single ' $n$ ').

obv. 4 For ${ }^{\mathrm{f}} \mathrm{AN}$ cf. SANTAG 4, 21 obv. 17 (transliterated ${ }^{\mathrm{f}}$ DINGIR).

fUwurui could be based on the element in the PN fUwur-waše (suggested by Maynard Maidman),

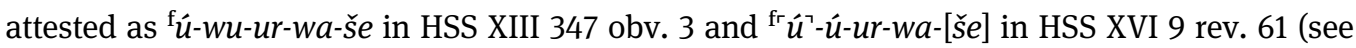
NPN 169a and AAN 163). SANTAG 4, 21 obv. 19 writes f $u$-wa-ru-i. The ending -ui is well attested among the Hurrian female PNs from Nuzi, as seen in names such as ${ }^{\mathrm{f}}$ Aštui (AAN 36a), ${ }^{\mathrm{f}}$ Awelli-kui

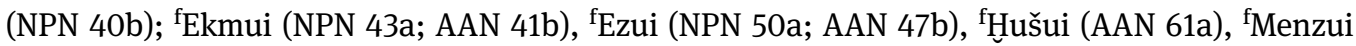

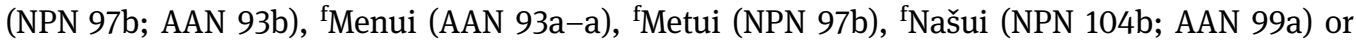
fTakui (NPN 145b).

obv. 5 For the various attested writings of the name ${ }^{\mathrm{f}} \mathrm{Ah} a \bar{t}-\mathrm{abīša}\left({ }^{\mathrm{f}} a\right.$-hna-at-a-bi-šá, ${ }^{\mathrm{f}} a$-h $a$-ta-bi-ša or ${ }_{\mathrm{f}} a$-h $a$-ta-bi-šâ) see NPN 10a and AAN 13a.

obv. 7 f Ewellat-kui might be identical with that in Gadd 82 obv. 8: ${ }^{\mathrm{f}} e-b e-{ }^{\top} e l^{\top}-[. .$.$] , since there is much$ overlap among the names of these two texts. If so, it would be another example for the alternation of $w / b$ in the Nuzi texts: see, e.g., the name written ${ }^{{ }^{\mathrm{m}}}$ na-ar-wi-lu or ${ }^{\mathrm{m}}$ na-ar-bi-DINGIR (see NPN 104b sub NARBĪ-ILU [MacRae read: Nawr-ilu]).

obv. 8 For fHazipa see SANTAG 4, 35 obv. 2 (fha-zi-pa) and JEN 531 rev. 20 (f ha-zi-ba).

For fHutil-lumti cf. SANTAG 4, 21 obv. 8, where the name is written 'hu-ti-lu-um-ti, with single 'l'. This is the fourth female name of the Nuzi corpus attested so far that uses the place name Lubti/ Lumti (see RGTC 10, 166-168) as second element. The other examples are fHašil-lumti (NPN 57a;

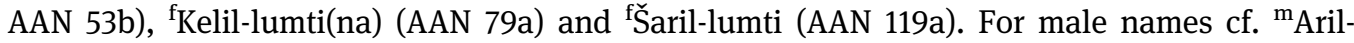
lumti (NPN 27b; AAN 28a), ${ }^{\mathrm{m}}$ Arip-lubti (NPN 29a) and perhaps also ${ }^{\mathrm{m}}$ Kipal-rumti (NPN 86b, see NPN 232a).

obv. 9 ${ }^{\mathrm{f}}$ Mušati could be an abbreviation of ${ }^{\mathrm{f}}$ Mušatil: cf. ${ }^{\mathrm{f}} m u$-ša-ti-il and ${ }^{\mathrm{f}} m u$-ša-ti-el in JEN 430 obv. 2, 6, 9 . obv. $10 \quad$ For ${ }^{\mathrm{m}}$ Enniri cf. SANTAG 4, 36 rev. 8. For ${ }^{\mathrm{f} P a i m a}$ cf. SANTAG 4, 21 obv. 3, 136 obv. 4 ( ${ }^{\mathrm{f}} p a-i-[)$, and CT 51, 7 rev. 12 ( $\left.{ }^{\mathrm{f}} b a-i-m a\right)$.

obv. 11 For Šsatuia see also SANTAG 4, 21 obv. 9, 35 obv. 4, and Gadd 82 obv. 5.

$\mathrm{m}$ ! (text $\left.{ }^{\mathrm{f}}\right)$ Dugul-ilī. Some Nuzi names are identical for men and women, such as Gimill-ištar (AAN 81b), Kinzi (NPN 86a; AAN 82b), Kīnu-ḩabil (AAN 82b), Kipali (AAN 82b-83a), Pentammu (AAN 108b), Warhi-nuzu (AAN 165b) and Zilia (NPN 177b-178a; AAN 172a), but that this person is a man can be seen in the tablets parallel to this ration list, where it is written ${ }^{\mathrm{m}} d u$-ug-li-DINGIR

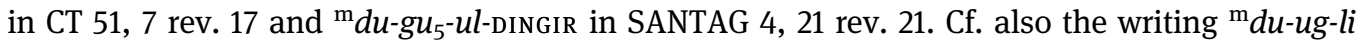
(without DINGIR) in TCL IX 22 rev. 23' and SANTAG 4, 34 obv. 2.

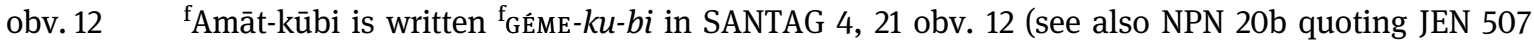
obv. 4).

obv. 13 In NPN 41a the writing ${ }^{\mathrm{f}} A$-ze is understood as a variant for ${ }^{\mathrm{f}} A z$-ze. This new text as well as SANTAG 4, 21 (obv. 4 and 11) seem to indicate that these are two different names (see obv. 15 for ${ }^{\mathrm{f}} A z-z e$ ), here to be distinguished as Aze and Azze.

obv. 14 Ifwaia was rendered Iwiina in SANTAG 4, 21 (obv. 11).

The first element of the Hurrian female PN f̌sumalla- ${ }^{d}$ ištar is certainly derived from the same root as the male PNs ${ }^{\text {m}}$ Šumala and ${ }^{\text {m}}$ Šumaliia (see NPN 138a and AAN 131b). Ištar is a well-established goddess of the Hurrian pantheon in the kingdom of Arraphe. She had a temple in both Nuzi (Istar nuzohhe, see HSS XIV 237: 4'; HSS XV 57: 7; see also RGTC 10: 208) and Al-ilāni, i.e. the capital Arrapha (Ištar ninuawe, see HSS XIV 106: 9, 11; see also RGTC 10: 16). Occasionally, this goddess appears as an element in both female and male PNs, such as ${ }^{\mathrm{m}}$ Atanah-ištar (AAN 37a), ${ }^{\text {fHemalla- }}$ ištar (NPN 60a), mIbnī-ištar (NPN 71b, AAN), f Ištar-aḩāt (NPN 74b), fištari-kui (AAN 71b), f'̌štar-māti (AAN 71; or frštar-madi from Hurrian mad-, 'to be clever, wise'), f Ištar-bēlt-ekalli (AAN 71b), fištarummi (NPN 74b; AAN 71b-72a), ${ }^{\mathrm{m}}$ Gimill-ištar (AAN 81b), ${ }^{\mathrm{f}}$ Gimill-ištar (AAN 81b), ${ }^{\mathrm{m}}$ Mār-ištar

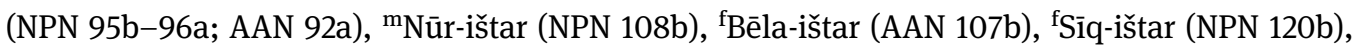
fṢulūlī-ištar (NPN 181b), mŠēp-ištar (NPN 132a), mŠūt-nabī-ištar (NPN 141a), ${ }^{\mathrm{f}}$ ta-an-di-ni-iš-tar 


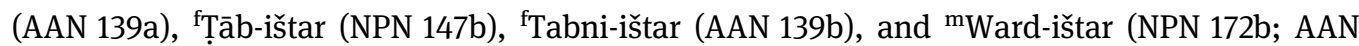
166a). But note that in the Nuzi texts Ištar is commonly written either syllabically (iš-tar) or logographically as ${ }^{d_{U}}$ (in most cases) or ${ }^{d_{E S} \check{S}_{4} \cdot D A R}$ (see NPN 301a). Only one other example in the published Nuzi texts has ${ }^{\mathrm{d}}$ INNIN. Mār-ištar in JEN 302: 18 (DUMU- ${ }^{\mathrm{d}}$ INNIN). According to the hand copy of Edward Chiera, the sign INNIN looks like ŠUR, as it does in this text as well. JEN 302 was written by Taia (the son of Apil-sîn) for Tehip-tilla, which dates the tablet to the second generation of the scribes of the Apil-sîn family. Therefore, the scribe of JEN 302 did not write this document. (See above for the dating of SANTAG 4, 34; perhaps the evidence from SANTAG 4, 34 should not be applied to BM 86005.) The logogram InNIN could indicate influence from a Babylonian expert on the scribes of the tablets in question. (The scribe Apil-sîn was most certainly Babylonian.)

obv. 16 For ${ }^{\mathrm{f} K u n n u}$ cf. Gadd 82 obv. 12: [ $\left.{ }^{\mathrm{f}}\right] k u$-un-nu (see NPN 91a) and SANTAG 4, 21 obv. 15: ${ }^{\mathrm{f}}$ ku-un-nu. In HSS XIV 642 obv. 12, the name is written ${ }^{\mathrm{f}} k u$-un-ù (quoted AAN 87 a as ${ }^{\mathrm{f}} \mathrm{KUNU}$ ).

lo. edge $21{ }^{\mathrm{f} A t t u r r u}$. This reading was a suggestion of Maynard Maidman. Cf. SANTAG 4, 21 obv. 20, where the name is written ${ }^{\mathrm{f}} a d$-dur-rù.

rev. 22 f Annuteti is most probably Hurrian, to be compared with other female PNs with a first element annu- such as ${ }^{\mathrm{f}}$ An-nu-ut-e-ra (NPN 22a), ${ }^{\mathrm{f}}$ Annu-kenni (AAN 24a written ANNUKIENNI; but cf. ${ }^{m}$ Kenni [NPN 83b; AAN 80b] for the second element) or ${ }^{\mathrm{f}} A n-n u-p a-[. .$.$] (AAN 24a). The second$ element, -teti, could be the same as the female PN ${ }^{\mathrm{f}}$ Tete, written ${ }^{\mathrm{f}}$ te-e-te (AAN 146a).

rev. 23 For ${ }^{\mathrm{f} K u t i a n i}$ cf. Gadd 82 obv. 4, where the name is written ${ }^{\mathrm{f}} k u-d i-{ }^{\ulcorner} a-n i^{\urcorner}$(see NPN 93a).

rev. 25 For Hurrian kuduktu, a measure for wool weighing 1.5 ma.NA $( \pm 711$ g.), probably the expected weight of one fleece, see Wilhelm 1988.

\section{BM 95280: A Fragment from the Lower Right Part of a Contract}

The only entirely legible line on this fragment from the lower right part of a contract (Fig. 2) is line 7', giving the name Hupita, son of Pukkita, whose seal has been rolled over the clay above the line. Hupita also sealed the contract JEN 294 (rev. 32 and 37), a țuppi tidennūti, ${ }^{5}$ according to which Tarmi-tilla, son of Šurki-tilla (and grandson of Tehip-tilla), received a field as a pledge for 10 years. So Hupita, son of Pukkita, comes from the fourth generation of the Tehip-tilla family and from the third to fourth generation of the family of scribes of Apil-sîn (see Friedman 1987: 117-118). This fragment was probably unearthed at Nuzi with the other tablets of the archive of Tarmi-tilla.

The measurements of BM 95280 are $42^{+} \times 42^{+} \times 17^{+} \mathrm{mm}$ (Fig. 2). ${ }^{6}$

\section{Transliteration and Translation}

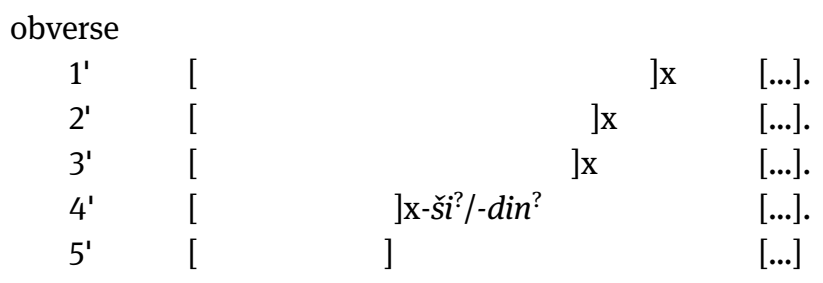

lower edge

$6^{1} \quad\left[\mathrm{NA}_{4} \cdot \mathrm{KIŠIB}^{\mathrm{m}} n\right] i^{?} \cdot r a-r i \quad[$ Seal of N]īrārī

5 For this kind of transaction, an antichretic loan, see Eichler (1973). For a discussion of the word tuppu and its correct writing in Akkadian, see Streck (2009: 136-139).

6 Following general conventions, the ${ }^{+}$-sign after a stated measurement indicates that the tablet is incomplete in the measured part. 
reverse

$7^{\prime}$ (seal impression a)

$\left.[\mathrm{N}]_{\mathrm{A}_{4}}{ }^{\mathrm{m} r} h u-b i\right\urcorner-t a$ DUMU pu-uk-ki-it- ${ }^{\ulcorner} a^{\urcorner}$ (seal impression $b$ )

(remainder of tablet is lost) (seal impression a)

[Se]al of Hupita, son of Pukkitta.

(seal impression b)

(remainder of tablet is lost)

BM 95280

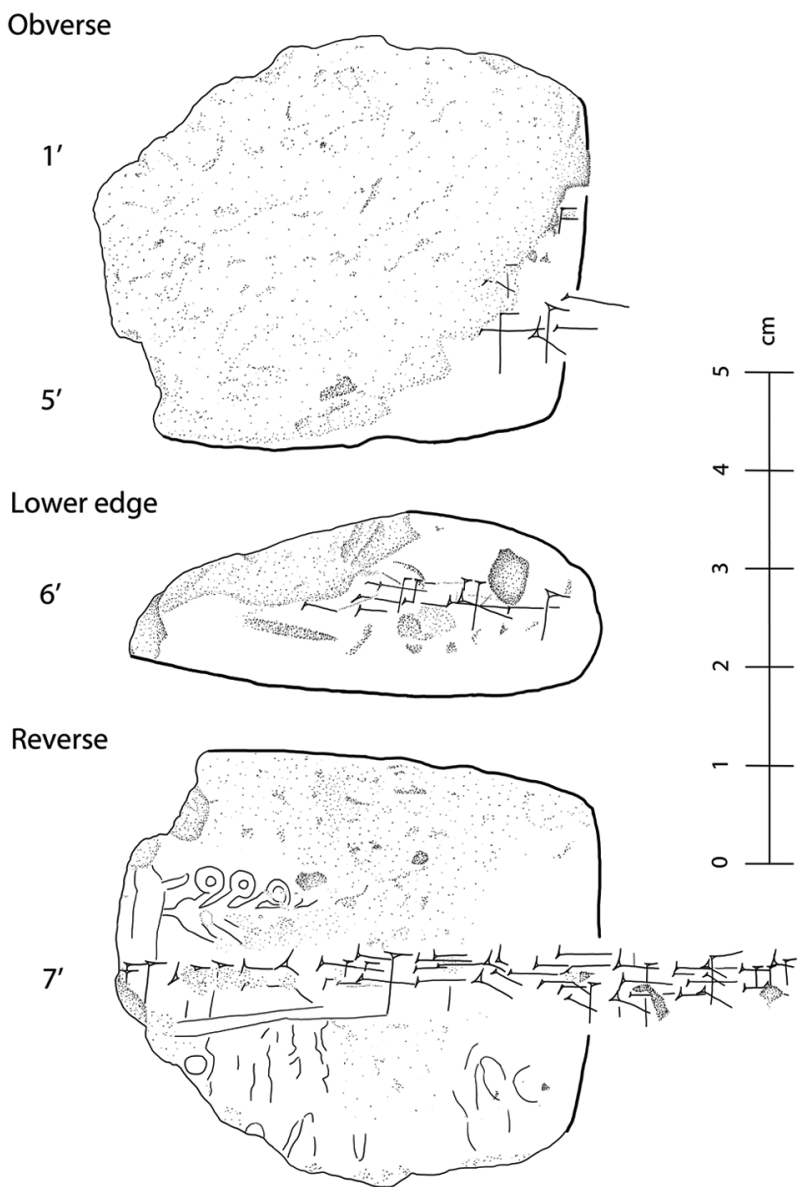

Fig. 2: BM 95280.

\section{Notes}

obv. 4' The reading depends on whether the slightly slanted wedge that begins above the head of the vertical is interpreted as part of this sign, which would then be read -din, or as belonging to the line above, which would lead to -ši.

lo. edge 6' Nīrārī's seal is unlikely to have been rolled over the space above this line, since there is not enough room for a sealing. The captions for the seal impressions are usually written below the sealings on those Nuzi tablets that use the complete width for the seal impression of just one person, as is the case with this tablet. Occasionally they are written above the sealing (e.g., HSS V 46; for photograph see http://cdli.ucla.edu/dl/photo/P393534.jpg). Nīrārī (see NPN 107a; AAN $101 \mathrm{a}-\mathrm{b})$ could be the name of the scribe of the tablet, in which case DuB.SAR would have been squeezed into the small gap on the lower left edge that is broken away just below line 6'. A scribe called Nīrārī (son of Taia and grandson of Apil-sîn) had been working for the two brothers Tarmi- 
tilla (JEN 108), and Ninu-atal (SANTAG 4, 72 [BM 85351]), and for two of their nephews, Ehliteššup (Gadd 76 [BM 17639]) and Puhi-šenni (SANTAG 4, 31 [BM 26268]), sons of Zike. So he would be a contemporary of Huupita, son of Pukkitta (line 7'). On the other hand, Nirrārī could simply be a witness of the transaction.

\section{Seal Impressions}

a) A standing human figure faces right with one arm raised. In front of the figure a volute standard seems to be placed horizontally, most probably in order to divide the image into two bands. The rest of the seal impression is lost.

b) Though very damaged, the traces seem to depict a row of standing figures.

Unfortunately no seal impression of Nīrārī, son of Taian, has been published, and the autograph of JEN III produced by Edward Chiera lacks the seal impressions, so that the seal of Hupita, son of Pukkutta, on JEN 294 cannot be compared with the seals on this tablet in order to establish whether or not the seal legends were written above or below the sealings (see notes to line $6^{\prime}$ ).

\section{BM 95463: A Fragment from the Reverse of a Legal Document}

This fragment with a beautifully preserved surface from the lower right part of the reverse of some sort of contract (Fig. 3) has the names of witnesses that sealed the transaction along with their seal impressions. The only names preserved are Mannu-māḩiršu (see NPN 95b; AAN 91b) as a patronym and Šati-kintar (see NPN 126b; AAN 121a) as a sealing witness. Only one son of Mannu-māhniršu is attested so far, Naniia (JEN 19 rev. 28), witness to a mārūti-transaction ${ }^{7}$ of Tehip-tilla, son of Puhi-šenni. The seal impression identifies Šatikintar as the person who also sealed a transaction by Enna-mati and Šurki-tilla, sons of Tehip-tilla (JEN 654 up. edge 45), and a court procedure concerning Zike, son of Akkuia, and fWarhi-matka (HSS V 46 rev. 24). This Šatikintar is identical with the judge Šati-kintar, son of Turi-kintar, as shown by HSS V 48 (see obv. 4), where he is named in a group together with the other judges named in HSS V 46 (Haiš-teššup and Turari). This supports the understanding of Dosch / Deller (1981: 101), according to which the name Šati-kintar is only attested within the Kassite family of Kizzuk. Thus, Šati-kintar would have witnessed the transaction of Tehip-tilla, son of Puhišenni (JEN 90 rev. 10' and 232 rev. 24; both with patronym), but also those of Tehip-tilla's sons, Enna-mati and Šurki-tilla, either alone (only Šurki-tilla; e.g., SANTAG 4, 117 [BM 95320] left edge 3' without patronym) or together (JEN 323: 20; 328: 30; 654: 45; all without patronym). This dates this fragment to the second and third generations of the Tehip-tilla family and to the second (or probably the third) to fourth generations of the scribal family of Apil-sîn (Friedman 1987: 216-217). With Šati-kintar affiliated with the Tehip-tilla family the fragment BM 95463, just as BM 95280 (no. 2 above), would have been found at Nuzi rather than in Arrapha.

The measurements of BM 95463 are $36^{+} \times 47^{+} \times 14^{+} \mathrm{mm}$ (Fig. 3).

\section{Transliteration and Translation}

\begin{tabular}{|c|c|c|c|}
\hline $1^{\prime}$ & $-p$ & & {$[\ldots]$. } \\
\hline reverse & (seal impression) & ] & [(seal impression)] \\
\hline $2^{\prime}$ & {$\left[\mathrm{NA}_{4}\right] \cdot{ }^{\ulcorner} \mathrm{KIŠIB}{ }^{\mathrm{m}} \mathrm{x}(\mathrm{x})-k i^{\urcorner}-\mathrm{x}[$} & ] & [S]eal of ...[...] \\
\hline
\end{tabular}

7 For this kind of transaction see recently Fincke 2010. 


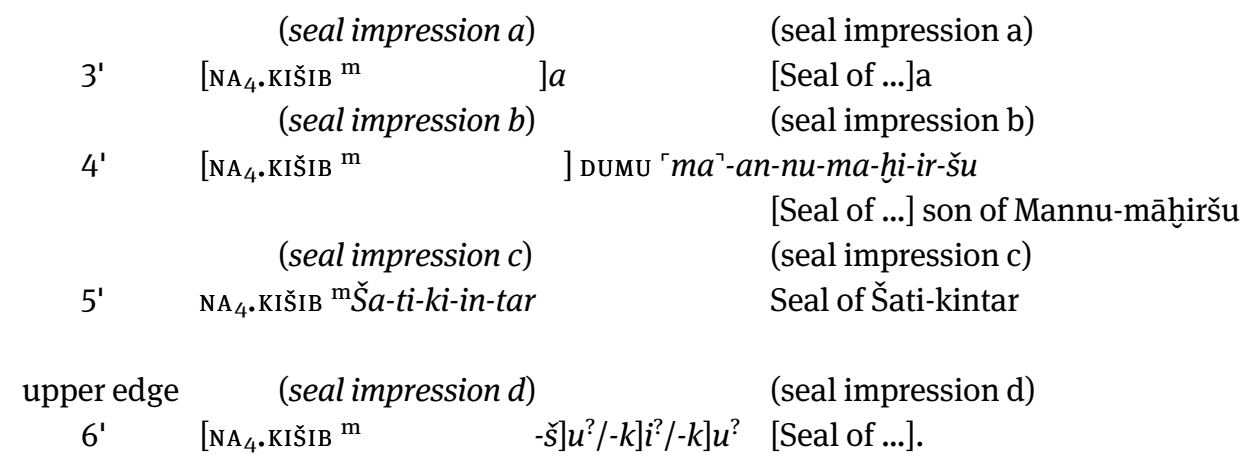

BM 95463

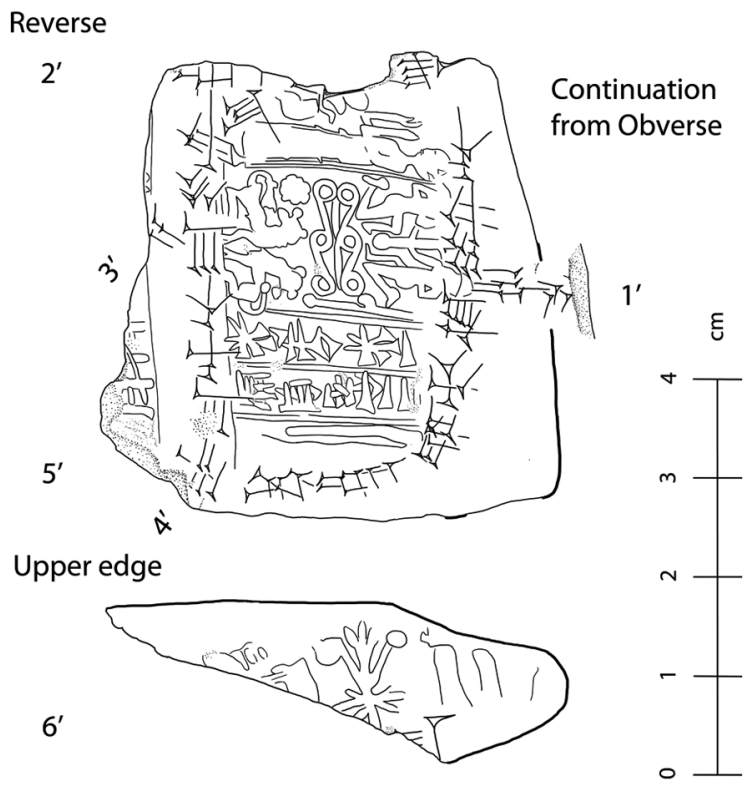

Fig. 3: BM 95463.

\section{Seal Impressions}

a) On the upper left part of the reverse, above and following the sign - $a$, are traces of a seal impression that is not part of the sealing that can be seen at the lower left, because the line with the name of the seal owner ending on - $a$ separates the sealings from one another.

b) On the lower left part of the fragmentary reverse the remains of a cuneiform sign from the legend of a seal can be seen, the owner of which is most likely the son of Mannu-māhiršu.

c) The seal of Šati-kintar visible in the centre of the reverse is divided into three segments; from left to right: (1) A beardless male figure facing left with both hands raised and standing in front of something that seems to be flanked by another standing person facing to the right, only one arm and the back of which are visible to the right of the legend. On another impression of this seal, the figure between the two standing individuals can be identified as a nude female standing with hands at her waist or lower chest (HSS V 46, for a photograph see http://cdli.ucla.edu/dl/photo/P393534.jpg). (2) A segment divided by a branch device into two antithetically organised scenes. Above kneel two human figures each on one knee with one arm on the waist or lower chest and the other raised (due to the way this seal is rolled over the clay, the arm of the right figure seems to point downwards) to frame a standard; and in the lower scene 
appear two animals (perhaps lions) with their chests towards each other, but with their heads turned backwards. (3) A legend of two lines: ${ }^{8}$

$$
\begin{array}{ll}
1 & {[\mathrm{KIISI}]_{\mathrm{B}} \mathrm{m} \text { ar-ru-um-[x] }} \\
2 & {[\mathrm{I}]_{\mathrm{R}} \mathrm{d}_{\mathrm{IS} K \mathrm{KUR}}{ }^{\mathrm{d}} \text { [UTU] }}
\end{array}
$$

The name ${ }^{\mathrm{m}}$ Arrum-[x] should probably be restored as Arrumpa with $b a$ or $p a$ (NPN 36a); a restoration to ${ }^{\mathrm{m}}$ ar-ru-um-[ti/di] is less likely (see NPN 36a with reference to Aril-lumti [NPN 27b; AAN 28a]). This means that Šati-kintar used a seal that was cut for someone who was, as far as we know, not a member of his family (see Dosch / Deller 1981).

Fragments of other impression from this seal have already been published: for all three segments partially visible in the sequence 1-2-3 see JEN 654; for the sequence 2-3-1 see SANTAG 4 Tafel CXXI (BM 26242); for fragmentary segments 1 and 2, see SANTAG 4, 117 B, Tafel CXVIII (BM 95320). For another seal of Šati-kintar, son of Turi-kintar, with the same layout but different motifs and a legend, see Porada 1944-1945: Plate XLIX no. 994 (JEN 90).

d) On the upper edge traces of a further seal impression can be seen. Two human figures(?) facing to the left stand to the right of a volute tree. Although scenes with volute trees are usually portrayed antithetically (see Stein 1993: figs. VI-XI Group 2), there seems to be a different scene to the left of the tree, but the traces of the depicted motifs are too poorly preserved for identification.

\section{BM 103203: A Middle Assyrian Letter Dating to the Aftermath of the Conquest of the Kingdom of Arraphe}

This small, almost square tablet (Fig. 4) is a Middle Assyrian letter sent to a certain Uthia, a name well known from the Nuzi texts (see NPN 75b and AAN 72a, s.v. Ithia). Yet it was written by a man living under the aegis of the Middle Assyrian kingdom, a situation that raises questions about the archaeological provenance of the tablet. Christopher Walker kindly provided information from the Museum records concerning this tablet indicating that BM 103203 belongs to a group of 150 artefacts consisting of cuneiform tablets, cylinders and stone jars, which the BM bought from the Parisian dealer I.E. Gejou. The objects were registered at the BM under the number 1910-10-08 (8 October, 1910). Apart from BM 103203, the tablets of this group of 150 objects consist of mainly Old Babylonian archival texts, but also two Middle Assyrian administrative texts, ${ }^{9}$ four Neo-Assyrian documents ${ }^{10}$ and one Neo-Assyrian literary text. ${ }^{11}$ In correspondence with E. Wallis Budge between 1909 and 1911 Gejou twice offered the BM Nuzi tablets, two from 'Kerkouk' (Kirkuk / Arrapha) on 31 December, 1910, and a black tablet from 'Kerkouk' and a tablet from 'Sherqat' (Ǎšsur) on 5 January, 1911. Since there are no other Nuzi texts identified among the tablets registered by the BM as coming from Gejou after that date (more than 1100 pieces had been registered with the date 1911-04-08), the individual allotments sent by this Parisian dealer during 1910 and 1911 could easily have been confused and wrongly numbered at the BM, ${ }^{12}$ so that BM 103203 might be one of the tablets Gejou mentioned in his letters, despite its light colour. ${ }^{13}$

\footnotetext{
8 Irving Finkel kindly assisted me in reading the name on this seal legend.

9 An inspection of both Middle Assyrian tablets in November 2013 revealed that BM 103207 is an undated receipt of qupātu-flour and bread as a food allotment (NINDA naptunu), while BM 103200 is an allotment of items dated limmu Ibri-šarri (rev. 10-11: ITU.ku$z a l$-lu Ud.'22.кÁм' / li-mu ib-ri-мAN), which would be one of the first years of Tukulti-apil-ešarra I (Tiglath-pilesar I). Both tablets will be published by Jaume Llop and me.

10 BM 103202 (ZA 73, 239-240, 251 no. 8), BM 103204 (unpublished), BM 103205 (ZA 73, 245-246, 252 no. 12) and BM 103206 (ZA 73, 241-242, 252 no. 9).

11 BM 103187 contains an incantation. For the Assyrian material of this group see Lambert (1992: 76).

12 From other collections we know that allotments could be backdated during the registration process.

13 BM 103203 was fired at the BM in January 1963. This process would not have changed the typical black colour of a Nuzi tablet into the present light beige colour of this tablet. Perhaps the BM decided not to buy either of the Nuzi tablets offered by Gejou in 1910 and 1911.
} 
An interpretation of the letter and the possible background of the sender are given in the commentary below.

The measurements of BM 103203 are $39.5 \times 38 \times 18 \mathrm{~mm}$.

BM 103203

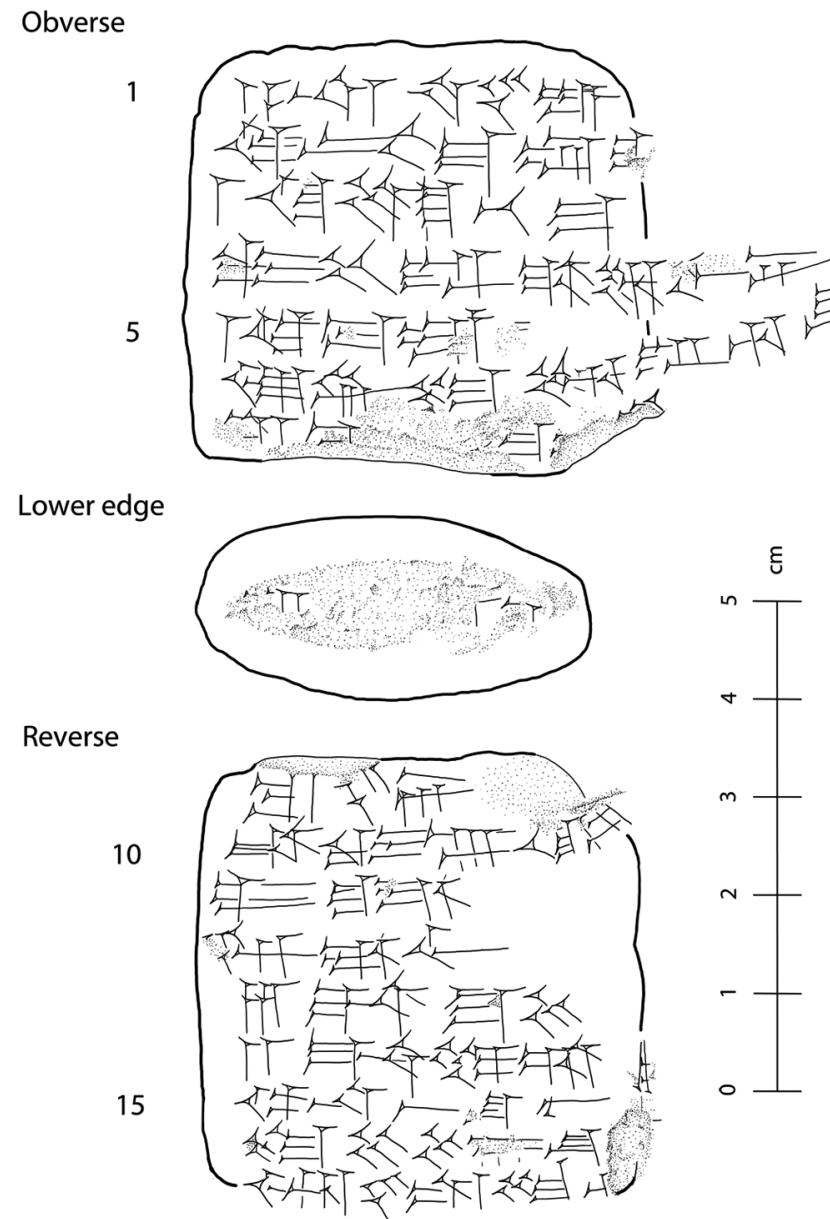

Left / upper edge

20

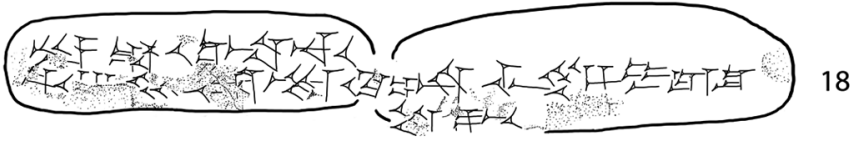

Fig. 4: BM 103203.

\section{Transliteration and Translation}

obv. $1 \quad a-n a^{\mathrm{m}} u t-h \mathrm{i}$-ia

To Uthia

2 qí-bi-ma um-ma

$\mathrm{m}_{k i-t e-k u-b e-m a}$

speak, thus (says)

4 ANŠE.KUR.RA ša $u s^{-}{ }^{\ulcorner} b u^{\urcorner}-n i$

Kidi(n) ${ }^{\text {-kūbi }}$

5 mki-ba-ia

6 ù LÚ.tu-UZ-ra-ḩu-šu

'The horse(es) that stayed (here),

7 ‘ š $^{? ?}-t\left[a^{?}-\mathrm{x}\right] \mathrm{x} \mathrm{x}[\mathrm{x}] \mathrm{x}$

Kipaia

and the ... man

they? have ... 


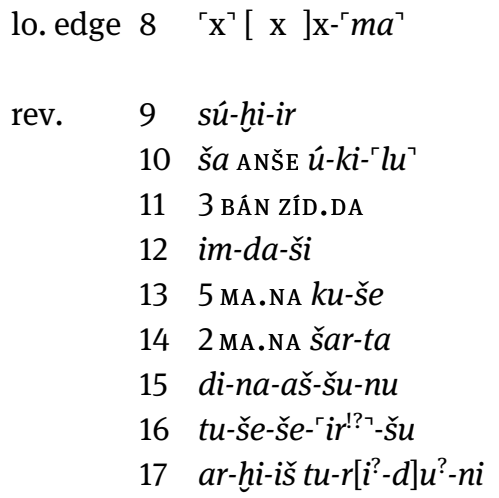

up. edge $18 \quad a^{!}-n a \check{s} i-{ }^{-} \check{s} a r^{\urcorner} i-l u-{ }^{\ulcorner} k u{ }^{\urcorner}$

le. edge 19 ' $\mathrm{ITU}^{\mathrm{IT}}$ '̌a ke-na-ti

20 'UD.16. KAM $\left.\left.^{\star} l i\right\urcorner-m u{ }^{\mathrm{m}} k i-{ }^{\ulcorner} t e-k u\right\urcorner-b e$
... and?

the foal

of the donkey they kept back.

3 BÁn flour

he forgot.

5 minas of hide

2 minas of hair (or pelt)

give out to them.

You should prepare this

(and) you should tra[vel dow]n (here) quickly.

To Šiššar they should come.

Month ša kēnāte, day 16, lìmu Kidi(n)? -kūbi.

\section{Notes}

obv. 3, rev. 20 The name of the sender is identical to the limu-name in line 20: on the date of the letter see below under The Date of the Letter.

obv. 4 bThe verb usbuni, the third singular preterit of wašābu, 'to sit down; dwell, stay; exist, be (currently)', with the Assyrian subjunctive in - $u$-ni, would refer to 'the horse'. It could also function as a third plural preterit, since the logogram ANŠE.KUR.RA does not require the plural marker. In a Middle Assyrian letter order from Harbe, the verb wašābu occurs in connection with horses (Tell Chuēra no. 4, 3-5; Jakob 2006: 43-45): ANŠE.KUR.RA.MEš šá PN i+na URU.ḩar-be lu us-bu le-ku-lu, 'The horses of PN shall stay in Harbe (and) feed' ${ }^{14}$ Another possibility would be to understand the verbal form as from wașābu, 'to add' (AHw 1474b, CDA 435a; cf. așābu CAD A II 352), which would yield the translation 'The hors(es) they added'.

obv. 5 The name Kipaia is well attested among the Nuzi texts, see NPN 86b and AAN 82b.

obv. 6 As the horse is the topic of the instruction in 1l. 4-9, it would be attractive to connect tu-UZ-ra$h u$-šu with the D stem of șarāhuu, șurruhu, known only from Middle Assyrian texts referring to horses in the meaning 'to keep (them) warm' after training (see CAD Ș 99a). With the preceding LÚ this form cannot be interpreted as a verb, though, but must be a noun denoting an occupation or special function of that person. It cannot be derived from șarāhu, since tu- is not attested in Akkadian as a prefix for nouns. If it were a Hurrian term with the suffix for adjectives of appurtenance -he followed by the Akkadian possessive suffix -šu, we could postulate a root tuzror tuz-r-, but neither is listed by Laroche (1979: 274) or Richter (2012: 479).

obv. 7 The traces at the beginning of the line suggest a verb in the perfect, most likely plural, describing what the two persons mentioned in obv. 5-6 have done with or to the horses of line 4. Unfortunately, the remaining traces are not clear enough for a restoration.

lo. edge 8 The last sign could also be read ' $\check{s} u$ '.

rev.9 One would expect the accusative, suhīra. To interpret sú-ḩi-ir as the D-imperative of sahāru, 'to send; turn back', is unlikely. Similarly unlikely would be a reading șu-hii-ir, D-imperative of șehèru, 'to deduct, deplete'.

rev. 10 The sign Ú has a peculiar form with the lower horizontal wedge beginning further to the right than the upper one, which rather recalls MÁ.

14 I thank Jaume Llop for this reference. 
rev. 12

rev. 13

rev. 15

rev. 16

rev. 17

rev. 16-17 ready so that they may leave soon').

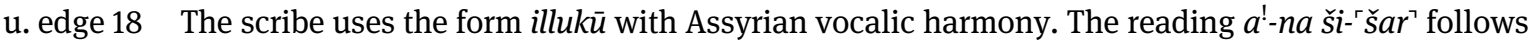
a suggestion of Jaume Llop (personal communication). Šiššar is the name of a watercourse near Aššur that has been identified with the Wādī at-Tartār (see RGTC 5, 317), west of Mosul. Since there is no indication of Šiššar being a watercourse in this text, it may refer here to a small settlement located at and named after this wadi. This would mean that the sender of this letter was stationed in the neighbourhood of Aššur.

le. edge 19 The month ša kēnāte is said to be the third month of the Middle Assyrian calendar (e.g., Hunger 1976-1980: 301), corresponding with the second month of the Babylonian calendar (e.g., Freydank 1991: 84). This identification, however, could be misleading, since no system of intercalation has been demonstrated for this period, so that the 'months' would advance slowly through successive solar years (Koch 1989: 132-141). For the Middle Assyrian calendar, see also CancikKirschbaum / Johnson (2011).

le. edge 20 Since the date formula was too long for the left edge of this small tablet, the scribe continued the second line on the upper edge, just below the last line of the letter.

\section{Commentary}

The letter BM 103203 can certainly be identified as a Nuzi tablet because of its general appearance, the ductus and the names Uthia (1. 1) and Kipaia (1. 5), Hurrian names well attested in the Nuzi texts. Closer inspection shows typical Nuzi as well as Assyrian features. The almost square format of the letter is also common among Nuzi tablets (cf., e.g., EN 9/1 99, 112, 114, 115, 119), while Assyrian letters are commonly written on oblong tablets in portrait orientation. ${ }^{15}$ The ductus shows some Middle Assyrian sign forms (ANŠE in ll. 4 and 10, LÚ in 1. 6, and TI in 1.19) among others that are typically Nuzi. The syllabary is typical for the Nuzi letters; Middle Assyrian scribes, e.g., do not use the sign DA for tá (see rev. 12). Although the text depicts a number of Assyrianisms (the Assyrian subjunctive in -u-ni in 11. 4 and 17, and illukū with vocalic harmony in 1. 18), other verbal forms lack these features (see rev. 12). It was evidently written under Assyrian influence, since the sender dates his letter according to Assyrian custom with the month, day and eponym (limu), as opposed to Nuzi tablets, which are never dated. While two names are evidently Hurrian, i.e. Uthia (l. 1) and Kipaia (l. 5), 
the name of the sender ${ }^{\mathrm{m}} k i-t e-k u$-be (1. 3), which is identical to the limu-name (1.20), is Assyrian, for which see further below.

These features point to an Assyrian scribe with a Hurrian background, ${ }^{16}$ writing to a Hurrian working on the sender's estate, perhaps located in Arrapha or nearby (we have noted the possibility that this letter was found in Kirkuk). ${ }^{17}$ If the scribe and the sender are the same person, he had found an occupation within Assyria proper. If it is also the case that sender and limu-name are the same person, he must have enjoyed a very successful career in the Middle Assyrian administration. ${ }^{18}$ The Assyrian king could have allocated landholdings in the former kingdom of Arraphe to him as compensation for his services to the Assyrian government or for military service. Still, one cannot exclude the possibility that a scribe had written the letter from dictation, and that the sender and limu-official are identical and genuinely Assyrian. In any case, the letter must have been written after the conquest of the kingdom of Arraphe by the Assyrian king in the late $14^{\text {th }}$ century BCE. It is obvious that part of the Hurrian population of Arraphe, i.e. those who had survived the military invasion and had not been deported to other parts of the Assyrian kingdom, ${ }^{19}$ continued to live in the area and to farm the land after the Assyrians had annexed their territory. The evidence for this is the number of people with Hurrian names mentioned in Middle Assyrian documents from that area, and the number and the kind of Hurrian loanwords that entered the Middle Assyrian vocabulary, ${ }^{20}$ even that of the royal administration. ${ }^{21}$ The rulers, of course, were Assyrians. This letter most likely witnesses the Middle Assyrian administration of the former kingdom of Arraphe.

\section{The Date of the Letter}

The eponym of the letter is written ${ }^{\mathrm{m}} k i-{ }^{-} t e-k u^{\top}-b e$, which is identical to the name of the sender (1. $3:{ }^{\mathrm{m}} k i-t e-k u$ be). As written by a Middle Assyrian scribe, this orthography would represent the name Kitte-kūbe ${ }^{22}$ or Qîti-kūbe, ${ }^{23}$ neither of which is so far attested as a limmu-name. It would thus be a new limmu-name dating roughly to the $14^{\text {th }}$ century BCE.

As written by a scribe with a Hurrian background this orthography could represent Kidi(n)-kūbe. ${ }^{24} \mathrm{~A}$ limmu Kidin-kūbe is known from the date formula in KAJ 29 (24-25: li-mu ${ }^{\mathrm{m}} k i-d i-k u$-bi / Dumu be-er-na-dinŠEš.MEš; Saporetti 1979: 49) and in VAT 19866 = Assur 14446 (24-25: li-mu ${ }^{\mathrm{m}} k i-d i n-k u-b i$ / DUMU d be-er-nadin-šE[š.MEš]; Freydank 1991: 148). Both Saporetti and Freydank date this eponym to the reign of Aššuruballit I (1363-1328 / 1353-1318 BCE). If this interpretation is correct, the limmu Kidin-kūbi can be regarded as the terminus ante quem for the Assyrian conquest of the kingdom of Arraphe. Regardless of whether this limu is to be placed towards the beginning or the end of Aššur-uballiț's reign, it would still prove that

16 In fact, it cannot be excluded that the scribe had a family background of any of the other people at the fringe of Assyrian dominion, because the non-Assyrian grammatical and writing features could as well go back to conventions of a scribe with another non-Semitic language as native tongue.

17 A location in or near Nuzi is less likely, although in the temple areas of Yorgān Tepe some remains of Middle Assyrian occupation were detected above the destruction levels represented by the Nuzi texts (Starr 1939: 122). The tell upon which Kirkūk is located, on the other hand, is very high and therefore most likely has more continuous layers of occupation. And Arrapha is in fact attested in Middle and Neo-Assyrian sources.

18 We do not know the circumstances under which a man, who obviously did not learn to write in the Assyrian heartland, who was most likely Hurrian in origin, and who possessed land in the former kingdom of Arraphe, might have become an official of such a high rank in the Assyrian administration that a limu would have been named after him.

19 See, e.g., Freydank / Salvini (1984).

20 As suggested by my research on the loanwords in Middle Assyrian vocabulary, to be published as a monograph, Some Indications for the Impact of Migration in the Neo-Assyrian Period (provisional title).

21 The Middle Assyrian administration, e.g., adopted the term ḩalșuḩlu/hassihllu from Hurrian halzuhlu (Jakob 2003: 18-19), and Hurrian words even entered the military terminology (Jakob 2003: 7).

22 See Postgate (1988: 125-126 text 53 line 3), who renders the name written ki-te-ku-bi Kitte-kūbi, which would mean 'Fidelity of Kūbe' (reference by the courtesy Jaume Llop).

23 PNAE 3/I: 1016a-1017a interprets the writings qi-te/i-..., qi-te/i-... and qit-ti-... in PNs as Qīîi-..., 'My end is ...'.

24 See the name Kidin(n)ìtu written ki-te-ni-du (see above, text 1 obv. 1). 
Arraphe was already annexed to the Assyrian kingdom during the reign of Aššur-uballiț. This would be in line with the assumed destruction of Nuzi $^{25}$ during the first regnal years of Aššur-uballiț, as first proposed ${ }^{26}$ by Wilhelm (1976: 160-162: around 1360 BCE, well before the death of Tušratta, based on a dating of his reign to 1365-1330 BCE), then modified by Stein (1979: 53: 1330 BCE, following the death of Tušratta, based on a reign of 1353-1318 BCE), ${ }^{27}$ and recently taken up by Maidman (2011: especially pp. 124-126: during the first years or first decade of Aššur-uballiț’s reign, before the death of Tušratta). Thus, this Middle Assyrian letter provides long sought after evidence for narrowing down the date of the Assyrian conquest of the kingdom of Arraphe.

Acknowledgement: All four tablets are published here by courtesy of the Trustees of the British Museum. My sincere thanks go to Christopher B.F. Walker, former curator of the Middle East Department at the BM, for bringing these four tablets to my attention. Additionally, he made unremitting efforts to trace the history of the tablet collection to which BM 103203 belongs in various Museum records. My sincere thanks are also due to Jaume Llop, Berlin, for his expert opinion on the Middle Assyrian letter and his suggestions for improved readings of difficult passages. Irving L. Finkel, Assistant Keeper of the Middle East Department, kindly helped me to read the seal legend of BM 95463, for which I am most grateful. Of course, my study of the cuneiform tablets would never have been possible without the assistance of the staff of the BM's Middle East Department that so supportively runs the Arched Room as a study area: I thank them all. Finally, I would like to acknowledge the assistance of the M4HUMAN fellowship of the Gerda Henkel Stiftung that enabled me to undertake my research on the cuneiform tablets of the BM. Thanks are also due to Jared L. Miller for carefully reading my manuscript and providing valuable suggestions for improvement. The manuscript that was submitted to AoF was completed in January 2014.

25 Stratum II of Nuzi, the level where the Nuzi tablets were found, was looted, destroyed and burnt, see Starr (1939: 48, 53, 58, 72, $83,103-104,142,173,178$, etc.)

26 Lewy (1959: 24) assumed the Nuzi archives ended 'a few years before 1362 B.C., the year when Aššur-uballit definitively threw off the Babylonian overlordship by making himself king of Assyria'. These events she dated after the death of Tušratta (see pp. 22-24).

27 Stein (1989: 58-59) gives a date for the end of the Nuzi texts as 1350, but is in favour of a later date as 1330. 


\section{Bibliography}

Baker, H. (2002): The Prosopography of the Neo-Assyrian Empire, Vol. 3/I: P-Ṣ, Helsinki.

Black, J. et al. (1999): A Concise Dictionary of Akkadian (SANTAG 5), Wiesbaden.

Cancik-Kirschbaum, E. / J.C. Johnson (2011): Middle Assyrian Calendrics, SAAB 19, 87-152.

Cassin, E. / J.-J. Glassner (1977): Anthroponymie et anthropologie de Nuzi, vol. 1: Les anthroponymes, Malibu.

Dosch, G. / K. Deller (1981): Die Familie Kizzuk. Sieben Kassitengenerationen in Temtena und Šuriniwe. In: M.A. Morrison /

D.I. Owen (eds.), Studies on the Civilization and Culture of Nuzi and the Hurrians in Honor of Ernest R. Lacheman on his Seventy-Fifth Birthday, April 29, 1981, Winona Lake, IN, 91-113.

Eichler, B. (1973): Indenture at Nuzi. The Personal tidennūtu Contract and its Mesopotamian Analogues (YNER 5), New Haven, CT. Fincke, J. (1993): Die Orts- und Gewässernamen der Nuzi Texte (RGTC 10. TAVO, Reihe B, Nr. 7/10), Wiesbaden.

Fincke, J. (1995): Einige Joins von Nuzi-Texten des British Museum, SCCNH 7, 23-36.

Fincke, J. (1996): Weitere Joins von Nuzi-Texten, SCCNH 8, 273-280.

Fincke, J. (1998): More Joins Among the Texts from Arrapha (Kirkūk), SCCNH 9, 42-62.

Fincke, J. (2009): Drei bislang unerkannt gebliebene Nuzi-Fragmente des British Museum, SCCNH 18, 229-248.

Fincke, J.C. (2010): Zum Verkauf von Grundbesitz. In: J.C. Fincke (ed.), Festschrift für Gernot Wilhelm anläßlich seines 65.

Geburtstages am 28. Januar 2010, Dresden, 125-141.

Fincke, J.C. (in preparation): Some Indications for the Impact of Migration in the Neo-Assyrian Period (provisional title).

Freydank, H. (1991): Beiträge zur mittelassyrischen Chronologie und Geschichte (Schriften zur Geschichte und Kultur des Alten Orients 21), Berlin.

Freydank, H. / M. Salvini (1984): Zu den hurritischen Personennamen aus Kār-Tukultī-Ninurta, SMEA 24, 33-56.

Friedman, A.H. (1987): Toward a Relative Chronology at Nuzi, SCCNH 2, 109-129.

Gadd, C.J. (1926): Tablets from Kirkuk, RA 23, 49-161.

Hunger, H. (1976-1980): Kalender, RIA 5, 297-303.

Jakob, S. (2003): Mittelassyrische Verwaltung und Sozialstruktur. Untersuchungen (CM 29), Leiden - Boston.

Jakob, S. (2009): Die mittelassyrischen Texte aus Tell Chuēra in Nordost-Syrien (Ausgrabungen in Tell Chuēra in Nordost-Syrien

Teil III. Vorderasiatische Forschungen der Max Freiherr von Oppenheim-Stiftung Band 2 Teil III), Wiesbaden.

Koch, J. (1989): Neue Untersuchungen zur Topographie des babylonischen Fixsternhimmels, Wiesbaden.

Lambert, W.G. (1992): Catalogue of the Cuneiform Tablets in the Kouyunjik Collection of the British Musuem, Third Supplement, London.

Laroche, E. (1980): Glossaire de la langue hourrite (Études et commentaires 93), Paris.

Lewy, H. (1959): Miscellanea Nuziana, OrNS 28, 1-25.

Maidman, M.P. (1986): The Nuzi Texts of the British Museum, ZA 76, 254-288.

Maidman, M.P. (2011): Nuzi, the Club of the Great Powers, and the Chronology of the Fourteenth Century, KASKAL 8, 77-139.

Nashef, K. (1982): Die Orts- und Gewässernamen der mittelbabylonischen und mittelassyrischen Zeit (RGTC 5. TAVO, Reihe B, Nr. 7/5), Wiesbaden.

Owen, D.I. (1991): Text Fragments from Arrapha in the Kelsey Museum of Art and Archaeology, The University of Michigan, SCCNH 1, 455-468.

Porada, E. (1944-45): Seal Impressions of Nuzi (AASOR 24), New Haven, CT.

Postgate, J.N. (1988): The Archive of Šerua and his Family. A Middle Assyrian Household in Government Service, Rome.

Richter, Th. (2012): Bibliographisches Glossar des Hurritischen, Wiesbaden.

Saporetti, Cl. (1979): Gli eponimi medio-assiri (BiMes 9), Malibu.

Starr, R.F.S. (1939): Nuzi. Report on the Excavations at Yorgan Tepe Near Kirkuk, Iraq, Conducted by Harvard University in Conjunction with the American Schools of Oriental Research and the University Museum of Philadelphia, Vol. I Text, Cambridge, MA.

Stein, D. (1989): A Reappraisal of the "Sauštatar Letter" from Nuzi, ZA 79, 36-60.

Stein, D. (1993): The Seal Impressions (Catalogue) (AdŠ 9), Wiesbaden.

Streck, M.P. (2009), Review of E. Reiner et al. (eds.), The Assyrian Dictionary of the University of Chicago, Vol. 18: T, Chicago 2006, ZA 99, 135-140.

Wilhelm, G. (1976): Parattarna, Sauštatar und die absolute Datierung der Nuzi-Tafeln, Acta Antiqua 24, 149-161.

Wilhem, G. (1988): Zu den Wollmaßen in Nuzi, ZA 78, 276-283. 